Article

\title{
What Dimension of CSR Matters to Organizational Resilience? Evidence from China
}

\author{
Wendong Lv, Yuan Wei *D, Xiaoyun Li and Lin Lin \\ Business School, University of International Business and Economics, Beijing 100029, China; \\ lwd@uibe.edu.cn (W.L.); lixiaoyun_xixi@126.com (X.L.); linlinuibe@163.com (L.L.) \\ * Correspondence: weiyuan_uibe@126.com; Tel.: +86-188-0011-0533
}

Received: 17 February 2019; Accepted: 11 March 2019; Published: 14 March 2019

check for updates

\begin{abstract}
Prior work on corporate social responsibility (CSR) has focused mainly on its effects on the short-term performance of firms from developed countries. In this article, we shed light on its effects on organizational resilience, which is defined as the firm's ability to positively cope with environmental turbulence, and operationalized by long-term, improved sales growth and financial volatility. In line with this operationalization, we adopt CSR's performance-enhancing and performance-insuring mechanisms to disentangle the relationship between CSR and organizational resilience. Furthermore, we divide CSR into five dimensions, namely shareholder, employee, business, society and environment-related CSR, and respectively examine their impacts on organizational resilience. The empirical study on a large sample of public firms in China from 2010 to 2017 shows that CSR as a whole significantly increases the firms' long-term growth and reduces their financial volatility. As for the five specific dimensions, they all have a significant negative effect on financial volatility, and the employee, business, environment-related CSR are positively associated with long-term growth. Yet, the empirical results did not indicate significant associations between shareholder and society-related CSR and firms' long-term growth. This study first explores the impacts of CSR's different dimensions on organizational resilience. Also, we contribute to enriching the literature on CSR by examining the long-term performance-insuring effect of CSR with a quantitative analysis of emerging markets. Finally, we discuss some important managerial implications, as well as promising directions for future research.
\end{abstract}

Keywords: organizational resilience; corporate social responsibility; Chinese firms

\section{Introduction}

The turbulent changes in today's business environment, such as economic recessions, discontinuous technologies, non-traditional competitors, and regulatory upheavals, have increasingly attracted attentions to organizational resilience [1]. Both academics and practitioners have been widely discussing and exploring how companies can effectively respond to environmental changes, so as to maintain high-level financial performance over a long term [2]. Among the antecedents or enablers of organizational resilience concerned in extant literature, firms' engagement in corporate social responsibility (CSR) activities has been repeatedly mentioned to play a key role since it can provide a deep social foundation or reputation for buffering disruptions [3,4], as well as useful information and resources to support innovations [5]. However, the relevant literature is mostly based on conceptual and case studies, or empirical evidence from firms in developed countries [6]. Further, little work has been done through a quantitative analysis of firms from emerging markets.

With this in mind, we examine the impact of CSR on organizational resilience with a large sample of publicly traded, non-financial firms from China covering the period from 2010 to 2017. The reasons we choose Chinese companies in this study lie in two main aspects. First, due to the unstable regulatory 
conditions, unestablished industrial structures, and the intense, chaotic competition brought by rapid development, Chinese enterprises are likely to face more changes and uncertainties in their business environment, which makes them more vulnerable than those from developed countries. Second, as the concern about CSR in China comes far later than that in developed countries, the effect of Chinese CSR on organizational resilience may be different. The Kinder, Lydenberg, and Domini (KLD) database, for example, began to internationally provide ratings of corporate social performance in 1991 . While, the first official research report on Chinese CSR was released in 2009, and then Chinese listed companies were required to issue their annual CSR reports. In line with this, we aim at providing some new insights of CSR and its effects on organizational resilience with evidence from emerging markets.

In doing so, we first clarify the conceptualization and operationalization of organizational resilience. Defined as the ability of an organization to respond positively to environmental changes, organizational resilience is a latent, unobservable construct usually measured by its outcomes [6]. The most desired outcome of organizational resilience recognized in extant literature is a firm's persistent superior performance in the changing business environment [7]. In order to maintain superior performance over time, resilient companies should be able to both capitalize on opportunities and control the negative impacts due to environmental changes. Accordingly, consistent with the mainstream view [6-10], we operationalize organizational resilience as the ability to achieve both high-level performance growth and low-level financial volatility over a long term.

Then, we analyze the impact of CSR on firms' long-term growth and financial volatility respectively through the theoretical lens of CSR's performance-enhancing and performance-insuring mechanisms. The performance-enhancing view holds that CSR can promote performance growth by improving employee satisfaction and retention [11-13], social image [14], innovation performance [15-17], customer satisfaction [18,19], brand equity [20], investment efficiency [21]. The performance-insuring view on the other hand, claims that CSR can provide buffers and supports to absorb shocks, undertake appropriate responses when a company suffers from crises and adverse events, thus mitigating negative impacts and financial volatility $[22,23]$. Taken together, we argue that CSR is conducive to improving organizational resilience.

Furthermore, we separately explore the impact of CSR's specific dimensions on organizational resilience. According to the stakeholder theory [24], CSR practices involve varied stakeholders that have different influence on firms' daily business activities [25]. In line with this, scholars tend to classify CSR activities based on the specific stakeholders they concern [26]. Generally, two broad kinds of stakeholder are divided by their legal obligations with companies. Stakeholders that have a clear legal relationship with a company and/or directly affect its operations are regarded as internal stakeholders [27] or major stakeholders [28], and those that do not possess the above attributes are external or secondary stakeholders. By satisfying the interests of internal stakeholders, enterprises can effectively obtain key business resources and improve their organizational capabilities. While, through maintaining good relations with external stakeholders, enterprises can achieve social legitimacy and reputation that can also be converted into important business assets [29].

However, despite the widely accepted theoretical classification, the measurement of the two broad kinds of stakeholder varies among relevant empirical studies for some groups, e.g., customers, suppliers, creditors, shareholders, and governments, are either taken as external or internal stakeholders $[25,27,29]$. Since the broad classification may result in confusing and even conflicting conclusions, we adopt directly the most basic dimensions of CSR relevant to different stakeholders, namely shareholders, employees, supply chain members, environment, and society. With the examination of these five specific dimensions, we aim at providing more detailed, comprehensive, and precise insights into the relationship between CSR and organizational resilience.

According to the objectives mentioned above, this paper is structured as follows: First, we present a review of extant literature, which includes how to conceptualize and operationalize organizational resilience as the ability to realize high growth and low financial volatility over time, and how to formulate our hypotheses about the influence of CSR and its five specific dimensions on organizational 
resilience respectively from the theoretical lens of performance-enhancing and performance-insuring mechanisms. Next, we elaborate our research methods and the results of empirical analysis. Finally, we summarize our research findings, and discuss theoretical contributions, managerial implications, limitations and directions for future research.

\section{Theory and Hypotheses}

\subsection{The Conceptualization and Operationalization of Organizational Resilience}

Resilience is an interdisciplinary concept that covers a variety of research fields, including physics, ecology, engineering, psychology, economics and business management, which generally refers to the ability of a system to recover or even exceed its original state after being disrupted [30]. Originally, in materials science, resilience refers to the behavior and property of a specific material to return to its initial shape after being temporarily deformed or pressed by external forces. Ecological resilience means a system's ability to absorb changes or disturbances through reorganization or self-organization, thus maintaining the same function, structure, identity, and feedback [31,32]. Engineering resilience, defined as the ability to respond to unexpected events that can't be predicted before they happen [33], is related to system safety and high reliability organization and has been widely used in complex systems to cope with unexpected natural disasters and man-made crises [34-37]. In the field of psychology, researchers focus on how individuals can effectively recover, adapt and develop well in the face of adversities [38,39].

Recently, resilience is increasingly being applied in social innovation that focuses on the long-term growth through continuous self-renewal, rather than the recovery from a specific disruption, involving individuals, organizations, communities, regions and other social systems $[3,6,8,40]$. The main reason why both practitioners and academics paid attention to organizational resilience lies in the increasingly turbulent business environment. Nowadays, there are tremendous disruptive environmental changes that undermine the incumbents' advantages and increase their risk of business failures [1,41], such as technological discontinuities, regulatory upheavals, geopolitical shocks, industry disintermediation, abrupt shifts in consumer preferences, and emergences of non-traditional competitors. Therefore, it is urgent for enterprises to build their organizational resilience, namely the ability to successfully cope with the impact of environmental changes on their earning power and then realize their long-term survival and growth [2]. In this regard, studies on organizational resilience have provided various insights on its prerequisites or characteristics, ranging from business strategy, organizational structure, financial resources, human resources, leadership and culture, to stakeholder interactions.

As for the operationalization of organizational resilience, many scholars view organizational resilience as the positive performance outcome when an organization undergoes environmental changes. In other words, whether an organization is resilient depends on if it can maintain a certain level of performance or achieve a more desirable performance level under changing environment $[9,42]$. In line with this, organizational resilience is generally operationalized as stable financial growth in the face of environmental changes [43], which is referred to by Markman and Venzin [7] as "sustained superior performance" over the long run. Implicitly, two critical conditions or components are in the operationalization of organizational resilience, namely low volatility and high growth in financial performance namely performance [6,44]. In this regard, several studies have provided a composite assessment of organizational resilience to integrate these two criteria. For example, Markman and Venzin [7] combine a return on equity and its volatility data into a synthetic measurement of organizational resilience; Pal [9] uses the Altman's Z-score transition profile to operationalize organizational resilience through assigning the upward, positive transition to healthy business state a higher score than the downward one.

Accordingly, in this article we conceptualize and operationalize organizational resilience as a two-dimension construct with high performance growth and low financial volatility. Next, we will 
respectively specify the relationship between CSR, its five dimensions and organizational resilience in terms of performance growth and financial volatility.

\subsection{CSR and Organizational Resilience}

According to Mackey [45], CSR is defined as "voluntary corporate actions designed to improve social or environment conditions." Though CSR is not explicitly required by law, the social good it generates can in turn bring business benefits. The literature has discussed organizational relationships with a wide range of stakeholders that contribute to achieving organizational resilience, including employees, government, natural environment, suppliers, competitors and so on. Consistently, researchers have come to conclude that reciprocity-based interaction with stakeholders is essential to build organizational resilience. The core of the relationship between a resilient organization and its external environment lies in trust and reciprocity. In order to avoid being excluded and opposed by stakeholders in the business network, companies need to positively take part in the business system by way of benefiting other participants [41]. In the case study of telehealth innovation, Cho and Mathiassen [5] find that collaborations with participating individuals, groups, and organizations within the whole network related to hospitals are necessary for the telehealth innovation's effective implementation and further diffusion, since the potential interest conflicts of every participant may be significant obstacles that endanger its long-term sustainability.

Therefore, companies need to positively engage in CSR activities to establish a good relationship with various stakeholders, which can enable them to effectively identify environmental changes, and obtain the necessary resources and support to successfully achieve their organizational resilience. The important role of CSR in organizational resilience manifests in two distinct aspects, namely performance-enhancing and performance-insuring mechanisms. As Gao, Zuzul [3] suggest, corporate reputation can work as either a defense mechanism whereby it helps companies to buffer disruptions and threats, or offensive mechanisms whereby it further allows companies to capitalize environmental changes to create values. The engagement in CSR activities helps a firm to build its reputation and deep social foundation that can work as "meta resource" [3] to activate conventional business resources (e.g., technologies, labors, capitals and materials), thus allowing it to not only cushion environmental shocks and thus reduce financial volatility [46], but also create opportunities for business initiatives and therefore increase performance growth [6].

In terms of CSR's performance-enhancing mechanism, positive relationships with various stakeholders contribute to building a wide network of knowledge and resources that provides flexibility and efficiency for an organization's internal activities and supports its business plans for innovation and adaptation $[4,47,48]$. Specifically, a firm's CSR engagement can internally increase employee satisfaction and commitment that further promote employees' innovative behaviors [12-15]. Also, enterprises that strategically engage in CSR are likely to innovate their product and process to meet stakeholders' desires, which brings them distinguished competitive advantages for long-term performance growth [16,17]. Externally, CSR disclosures can improve corporate governance ratings [49], decrease information asymmetry [50], increase confidence in capital market [51], create access to finance [52], reduce investment-cash flow sensitivity [53], and improve investment efficiency [21]. Besides, the good reputation brought by CSR contributes to increasing customer satisfaction [18,20], bringing political benefits [54], and reducing social constraints in business operations [26]. Given the above, CSR creates favorable internal and external conditions for enhancing a firm's performance and growth.

In addition to performance-enhancing mechanism, scholars have increasingly focused on the insurance-like role of CSR in corporate performance [22,23]. Different from CSR's contribution to performance growth, the performance-insuring view emphasizes that CSR can buffer or cushion the negative impacts of disruptions, shocks, crises, and threats on a firm's performance, allowing it to avoid significant financial volatility. Several empirical studies have provided evidence for CSR's performance-insuring mechanism during unfavorable events, such as boycotts [55], wrongdoing or illegal behaviors [56]. Besides, when undertaking strategic risk-taking actions, a firm can also benefit 
from its engagement in CSR activities. High strategic risks do not always bring high performance, for there are various internal and external contingency factors [57,58]. In this respect, Su and Tsang [26] indicate that positive relationship with stakeholders can smooth the process of firms' product diversification and therefore bring desired financial performance. As Pal and Torstensson [4] point out, a deep social foundation along with goodwill, brand awareness, network relationships can act as a mask that protects an organization from sudden negative events, and provides the necessary time for it to absorb shocks and take appropriate responses.

Given the above analysis of CSR's performance-enhancing and performance-insuring mechanisms, we propose the following hypotheses:

Hypothesis 1 (H1). CSR is positively associated with a firm's long-term growth.

Hypothesis 2 (H2). CSR is negatively associated with a firm's financial volatility.

\subsection{Shareholder-Related CSR and Organizational Resilience}

Shareholder-related CSR activities include sound financial structures, transparent information disclosures, positive innovations, and high-level stock returns. The sound employment of funds is the basic rule for a firm to meet its shareholders' interests, since unsafe, unreasonable financial structure directly induces shareholders' financial losses, such as high-level debts [59] and excessive earnings management [60]. In addition, in order to create high-level of return for shareholders, companies need to continuously engage in product and/or technological innovations. Taken together, companies with a high level of shareholder-related CSR are likely to positively engage in innovative activities to improve profitability, while apply funds in a sound, prudent manner to avoid great financial risks. In this way, companies can steadily provide shareholders with high investment returns.

Shareholder-related CSR can contribute to the two aspects of organizational resilience, namely long-term growth and low financial volatility. As for low financial volatility, a sound financial structure embodied in shareholder-related CSR can not only act as a shock buffer or absorber during crises to reduce negative impacts on profitability [61], but also provide access to financial resources to support normal operations and maintain stable performance $[4,48]$. The company with a sound financial structure (e.g., a low debt ratio) is likely to have much unused borrowing power and deliver decent credit to the capital market [62], which allows it to obtain the necessary funds at favorable financing costs to support its survival and development strategies during crises [26]. Kachaner and Stalk [63] find in a survey of resilient family firms that a prudent attitude towards debt is one of the important reasons why their performance is less volatile than that of non-family firms during economic recessions. With a high level of debt, a firm's freedom of business decision-making may be limited, and large costs or sacrifices are likely to be required to meet financing needs. In this regard, Tognazzo and Gubitta [62] suggest that companies should seek high-level profits without an excessive dependence on debt when the economic conditions are good, so as to prepare necessary financial slack to come through harder economic times.

Enterprises with a high level of shareholder-related CSR are likely to actively engage in innovative activities, which directly contributes to the continuous growth of organizational performance. A company survival survey by Govindarajan and Srivastava [64] shows that the lifespan of modern companies is being greatly shortened. The author points out that since the development of technologies (especially digital services) has led to the quick, continuous emergence of new products or services, companies that do not keep innovating will be soon out competed by other players in the market. Innovation has been widely recognized in extant literature as an essential way for companies to achieve their organizational resilience, since companies can absorb and even capitalize environmental changes by developing new capabilities and adaptive strategies [65-68]. For example, Hamel and Valikangas [1] define organizational resilience as the ability of an enterprise to dynamically adjust 
its business model and strategy in response to changing circumstances, thus avoiding the negative impacts of business environment changes on its core profitability. Similarly, Reinmoeller and van Baardwijk [8] believe that resilience is the ability of an organization to achieve self-renewal through innovation, and accordingly define a resilient enterprise as the one that can continuously create high financial performance. Furthermore, Teixeira and Werther [2] argue that resilience refers to the organizational capability that enables continuous innovative activities, rather than the specific innovative activities, which requires systematic allocation of organizational resources, such as people, ideas, and management, to make innovation a source of continuous competitive advantages to superior financial performance.

Given the above analysis, shareholder-related CSR can both reduce financial volatility and promote long-term growth. Therefore, we propose the following hypotheses:

Hypothesis 3 (H3). Shareholder-related CSR is positively associated with a firm's long-term growth.

Hypothesis 4 (H4). Shareholder-related CSR is negatively associated with a firm's financial volatility.

\subsection{Employee-Related CSR and Organizational Resilience}

Employee-related CSR involves a safe and comfortable working environment, high level of investment in employee salaries and benefits, training of knowledge and skills, and emotional care and commitment.

Employee-related CSR can bring employees' positive and creative working behaviors [69], which ultimately contributes to organizational innovation and performance growth. The resilient organization focuses on investing in the improvement of organizational members' knowledge, skills and abilities through education, training, and work experience, as well as fostering their innovation awareness, so as to improve their work efficiency and equip them with the competencies necessary to deal with environmental changes [70,71]. In the case study of a family firm spanning more than 160 years, Yacob [72] indicates a good managerial succession system characterized as the long-term apprenticeship training is critical for the firm's longevity and sustainability, as the selected managerial successors are highly capable of undertaking changes or transformations that consistent with its values and goals in a careful and wise way. In addition, the resilient organization relies on an emotional investment and commitment to its employees, such as caring, fair treatment, respect, trust, and empowerment [73]. This can contribute to increasing employee job satisfaction and organizational commitment [13], encourage employees to respond flexibly to environmental changes $[1,15]$, and therefore generate competitive advantages and commercial interests [12]. In this respect, Kachaner, Stalk [63] find that rather than financial incentives, resilient family firms rely on a culture of commitment and goals to achieve trust, dedication, and efficient teams, which contributes to a high level of employee productivity during both good and bad times.

In addition to performance growth, employee-related CSR is conducive to decreasing financial volatility in hard times, since employees' loyalty, morale, solidarity and other positive emotions it cultivates are particularly important for companies to effectively respond to crises threats, or challenges, thus preserving their stable financial performance [74]. When encountering adverse events, rather than strike or resign, employees in the company with high level of employee-related CSR are likely to exhibit collectiveness, commitment, and collaboration [11], and therefore understand and work with the company to overcome negative impacts [6,75]. Several studies on resilient firms during economic crises have provided evidence for this point. For example, van Essen and Strike [76] find that compared to non-family companies in times of crisis, resilient family businesses adopt less layoffs and wage cuts, and the number of employees employed and employee benefits are more substantial; Smallbone and Deakins [43] find that rather than layoffs at large companies, resilient SMEs tend to retain and recruit employees, and motivate employees to try different ideas to generate revenues. Lampel and 
Bhalla [44] find that resilient employee owned businesses (EOBs) have better employee retention (measured by an increase in the number of employees) than non-EOBs, and their employees contribute more to financial performance (i.e., higher level of sales turnover per employee). In line with this, engaging in employee-related CSR can produce insurance-like effects on financial performance during environmental shocks.

Taken together, employee-related CSR can both reduce financial volatility and promote long-term growth. Therefore, we propose the following hypotheses:

Hypothesis 5 (H5). Employee-related CSR is positively associated with a firm's long-term growth.

Hypothesis 6 (H6). Employee-related CSR is negatively associated with a firm's financial volatility.

\subsection{Business-Related CSR and Organizational Resilience}

Enterprises are interdependent in the business ecosystem. In order to respond effectively to dramatic changes in the business environment, an enterprise should collaborate with other related entities to acquire access to key knowledge and resources, get support for its innovative activities [47], and provide diversified products or services with flexibility and low cost $[4,48,77]$. In this respect, Erol and Sauser [78] propose that enterprises should ally with business partners, customers, and suppliers to form an open, integrated, collaborative network. The authors argue that by doing this, "extended enterprises" can connect and integrate information, knowledge, resources, and processes of the whole network in a very effective and efficient way, and thus meet successfully the changing environmental needs.

Good relationships with participants in the business network, i.e., customers, suppliers, and competitors, contribute greatly to enhancing corporate value and accelerating performance growth. Specifically, this intimacy with customers can help an organization to obtain information on the improvement and innovation of its products or services, thus enhancing its brand awareness through continuously providing satisfactory customer experiences. According to Marwa and Zairi [79], continuous and excellent quality management is very essential for a company's longevity, which requires the commitment of its every members in their daily work, as well as its active attempt to improve facilities, practices, and methods to deliver better products or services to end customers. In a study of Chinese companies in the service industry, Zhang and Jin [80] find that customer-related CSR is conducive to promoting their success and growth. In addition, a resilient organization is likely to establish a wide-ranging business network with its suppliers and even competitors through partnerships, strategic alliances, merger and acquisition. This can help it to utilize resources beyond its own boundaries to flexibly increase diversified, customized products or services at a low cost [81], which not only increases its own economic value, but also brings benefits for every participants [82]. Also, such a business network is an important way for the organization to obtain critical information, maintain vigilance, and improve best practices. Asgary and Li [83] show that CSR aiming at the supply chain's efficiency can help companies to develop new products, create opportunities for growth, and achieve high financial performance in the long run.

In addition to performance growth, business-related CSR is beneficial to reduce firms' financial volatility. Winston [84] states that the good customer relationship management can provide protection against fluctuations in market demands, since companies can ensure stable or growing sales remain through active adjustments and innovations in line with customers' new needs, or stimulate and lead changes in consumer behaviors during the introduction of new products or services. Demmer and Vickery [70] indicate that resilient organizations tend to embed early in customers' supply chains to fully understand customers' needs, and therefore continuously provide creative, satisfactory solutions, which greatly distinguishes them from their competitors during economic recessions. Similarly, Sabatino [68] finds that customer-oriented strategic planning of marketing, sales and operations is 
a noticeable characteristic of resilient companies in the economic crisis, which helps them to reduce financial volatility caused by the recession. In addition, building trust and reciprocity with other business organizations is fundamental to protect a company from being rejected to join as a partner in the business network, which is especially important to get necessary support to effectively control risk and achieve resilience in the event of major environmental changes [41]. Zhang and Ma [85] find evidence that CSR activities can help companies in the transition economy to establish and consolidate good relationships with suppliers, which further contributes to achieving their business goals and creating extensive economic benefits.

Given the above analysis, business-related CSR can both increase long-term growth and reduce financial volatility. Therefore, we propose the following hypotheses:

Hypothesis 7 (H7). Business-related CSR is positively associated with a firm's long-term growth.

Hypothesis 8 (H8). Business-related CSR is negatively associated with a firm's financial volatility.

\subsection{Environment-Related CSR and Organizational Resilience}

Environment-related CSR practices are the actions or measures taken by an organization to improve the impact of its business operations on the natural environment. In a study of U.S-based companies, Ortiz-de-Mandojana and Bansal [6] show that by providing opportunities for perceiving environmental changes and creating flexible resource reserves, the social and the environmental practices have a positive impact on organizational resilience measured through improved financial volatility, sales growth, and survival rates.

On the one hand, engagement in environment-related CSR activities contributes to increasing corporate value. In this respect, Winston [84] points out that due to the declining availability and rising price of scarce resources, and severe ecological imbalances in the natural environment, reducing reliance on natural resources can make companies more flexible. The author further state that the companies, which lessen the use of natural materials, energy consumption and waste, and carbon emissions, are likely to acquire distinguished competitive advantages in the future. In other words, the active participation in environment-related CSR activities can help a firm to cut down its resource costs, avoid the risk of natural environment changes, and also create financial benefits in the long term [86]. In a study of Taiwanese manufacturing companies, Chang [17] finds that CSR can help firms to improve their innovation performance of green products, and therefore bring them high level of financial performance. In addition, in the capital market, investors react positively to the disclosure of a firm's environment-related CSR performance, that is, investors are likely to make an optimistic estimate of its future cash flow, which results in a rise in its stock price [87].

On the other hand, the environmental-related CSR helps a firm to mitigate the impact of negative events. Companies actively engaging in environment-related CSR can establish a "green" image, and then win favors from the public and especially the stakeholders who pay close attention to the natural environment [88]. This can help a company to mitigate the negative impacts of adverse events, since the public are likely to take into accounts of its previously accumulated "goodwill", and therefore have an attitude of understanding and support. For instance, Cho and Lee [89] find that environment-related CSR enhances investor confidence in the capital market, giving companies plenty of financing and investment opportunities. Similarly, Ortas and Moneva [46] find that stock investors have confidence in the future development of companies that focus on social and environmental goals, and therefore provide them with opportunities for self-adjustment, which make them more financially resilient during the economic crisis. This demonstrates that environment-related CSR has the performance-insuring effect whereby it helps companies to reduce financial volatility during negative events through provide the necessary resources and support to increase resilience. 
Giving the above analysis of environment-related CSR's performance-enhancing and performance-insuring mechanisms, we propose the following hypotheses:

Hypothesis 9 (H9). Environment-related CSR is positively associated with a firm's long-term growth.

Hypothesis 10 (H10). Environment-related CSR is negatively associated with a firm's financial volatility.

\subsection{Society-Related CSR and Organizational Resilience}

The society-related CSR is reflected mainly in a firm's charity, such as donations to some non-profit organizations and other activities for public good. The role of society-related CSR in organizational resilience lies mostly in the social reputation it brings, which can not only create value and improve performance for companies, but also reduce their financial volatility brought by environmental shocks.

Many empirical studies have found that charitable activities can significantly increase corporate value [90,91], enhance firm growth [74], and bring long-term benefits [92]. For example, File and Prince [93] indicate that charitable donations help companies to obtain both fame and fortune, that is, donations contribute to wining a good reputation and also pumping up product or service sales. Zhao [94] points out that donations help companies gain social legitimacy and political legitimacy, thereby facilitating the resources and capabilities needed for innovation to acquire desired innovation performance. Werner [54] demonstrates that political reputation is an important part of the reputation brought by a firm' society-related CSR. Political reputation can influence the attitude of policymakers, determine whether companies are qualified to attend in the regulators' policy-making process, and get access to support for innovative activities, preferential tariff and tax and other favorable policies, which creates great competitive advantages for companies [84,95]. Especially in emerging economies, engagement in society-related CSR can further convey to capital markets a firm's ability to fill institutional gaps [96], thus stimulating investors' interest and bringing financing opportunities for its to undertake business expansions. Therefore, the engagement in society-related CSR can contribute to a firm's performance growth.

Analogous to other dimensions of CSR, society-related CSR can also help companies mitigate the impact of negative events, and therefore avoid significant financial volatility. A company's activities for social welfare contribute to build a good social image and drawing close the distance between it and the public. As a result, it can acquire much trust, confidence and goodwill from the public [97]. In this respect, Godfrey [98] proposes a model of injury insurance for corporate philanthropy. The author believes that a firm's charitable activities (e.g., donations) can generate and accumulate moral capital among the public, which can greatly help companies to alleviate the image crisis caused by violations, prevent the sharp decline of trust, restore corporate reputation and therefore maintain stable financial performance under crises or shocks. Consistent with this, Zou and Li [19] find that charitable donations can weaken the spillover effects of brand crises in the capital market, and thus reduce the negative impact of the brand crisis on financial performance. In line of this, through providing needed understanding and support, these positive emotions can help enterprises effectively mitigate the negative impacts of adverse events.

Taken together, society-related CSR can both enhance long-term growth and reduce financial volatility. Therefore, we propose the following hypotheses:

Hypothesis 11 (H11). Society-related CSR is positively associated with a firm's long-term growth.

Hypothesis 12 (H12). Society-related CSR is negatively associated with a firm's financial volatility.

To sum up, the conceptual framework of this study is shown in Figure 1. 


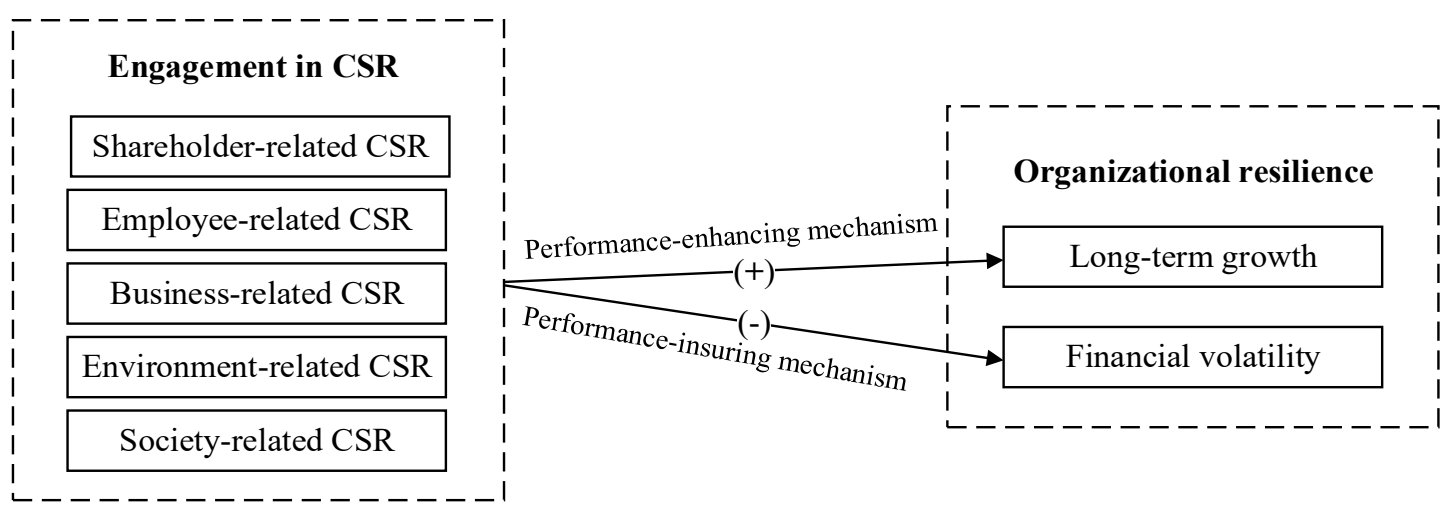

Figure 1. Theoretical framework.

\section{Methodology}

\subsection{Data and Sample}

This study argues that CSR-entire and CSR-related activities can provide organizational resilience, which is manifested in promoting long-term growth and mitigating financial volatility. We draw on non-financial listed companies during the period 2010-2017 from China to test our hypothesis. Among them, the CSR scores are obtained from the website of Hexun.com, and financial variables and stock returns are obtained from the China stock market and accounting research database (CSMAR). Excluding the abnormal or missing samples of financial data, we finally got 12,215 annual observations of 2444 listed companies. We conducted a two-way tail reduction processing of continuous variables at the $1 \%$ level.

\subsection{Variables}

The variables and their measurement in this study are shown in Table 1.

Table 1. Variable measurement.

\begin{tabular}{ll}
\hline \multicolumn{1}{c}{ Variable } & \multicolumn{1}{c}{ Measurement } \\
\hline Growth & $\begin{array}{l}\text { Dependent variables } \\
\text { The accumulation of net sales growth in three years (Unit: billion). } \\
\text { The standard deviations of monthly stock returns in each year. } \\
\text { Independent variables }\end{array}$ \\
$\begin{array}{l}\text { Total CSR } \\
\text { Shareholder }\end{array}$ & $\begin{array}{l}\text { The comprehensive score of Hexun CSR index. } \\
\text { Employee }\end{array}$ \\
Business & The shareholder score of Hexun CSR index. \\
Environment & The supplier, client and consumer score of Hexun CSR index. \\
Society & The environment score of Hexun CSR index. \\
& The society score of Hexun CSR index. \\
MB & The ratio of book value of equity to the market value of equity. \\
HHI & Industry concentration measured by the Herfindahl-Hirschman Index. \\
S\&A & Selling and administrative divided by the total assets at the end of fiscal year. \\
LEV & The ratio of total debt to the total assets at the end of fiscal year. \\
ACF & The ratio of cash flow to the total assets at the end of fiscal year. \\
SOE & SOE = 1 if the firm is a state-owned enterprise (SOE); SOE = 0 otherwise. \\
\hline
\end{tabular}

Dependent Variables. Organizational resilience in this paper is operationalized as long-term growth and financial volatility. We referred to Ortiz-de-Mandojana and Bansal [6] to measure these two dependent variables. We measured long-term growth as the accumulation of net sales growth over three years. Cumulative growth is a better measure of long-term growth than year-over-year 
growth because performance growth is likely to be continuous and incremental over time. Consistent with Thomas and Byard [99], Tognazzo and Gubitta [62], and van Essen and Strike [76], we selected three years as the time period to measure firms' long-term growth. Financial volatility was measured as stock return volatility. For each year, we calculated the standard deviation of the monthly stock return [100].

Independent Variables. In this study, we examine the impacts of CSR and its five specific dimensions on organizational resilience, which results in six independent variables, i.e., total CSR, shareholder, employee, business, environment, and society-related CSR. The measurements of these six variables were directly obtained from Hexun CSR dataset, which provides the annual CSR rating scores of all Chinese listed companies since 2010, the year after Chinese listed companies were officially required to issue their CSR reports. Hexun CSR dataset is regarded as the most comprehensive, latest, authoritative CSR database in China, and thus has been widely applied in relevant empirical studies [101,102].

Hexun evaluates a firm's CSR score based on five broad elements, i.e., the shareholder, employee, business, environment, society-related CSR activities. It further develops respectively a set of second and third-order indicators to evaluate these five elements. Appendix A shows all the 13 s-order indicators and 37 third-order indicators in total, as well their specific weights in following parentheses, which are assigned according to different industries. The source of data for evaluating the above indicators is Chinese listed companies' annual CSR reports and financial reports. According to the range of total CSR score, five grades are specified, i.e., CSR score in the range of $[100,80]$ is recognized for Grade A, $(80,60]$ for Grade B, $(6040]$ for Grade C, $(40,20]$ for Grade D, and lower than 20 for Grade E.

Control Variables. We adopted firm and year fixed effect regression method, which controlled for some time-invariant attributes of a firm. In addition, the following control variables were included. First, we controlled for market-to-book ratio since it has great explanatory power for the long-term performance [103] and stock return [104]. Second, we used the Herfindahl-Hirschman Index (HHI) — calculated by the square sum of the fifty largest enterprises' market share in a certain market- to take industry concentration into account, for enterprises within a highly centralized industry may favor monopolistic advantages and therefore are likely to sustain stable high performance $[76,105]$. Third, because slack can provide sufficient funds for enterprises to respond to environment turbulences [62], we controlled for and measured slack through three variables, i.e., selling and administrative expenses, leverage and cash flow $[29,76,106]$. Finally, since Chinese state-owned enterprises that fulfill political objectives are likely to have easier access to resources, we used a dummy variable to control for enterprises' nature.

\subsection{Results}

Table 2 shows descriptive statistics and correlation matrices. All the six independent variables are significantly positively correlated with long-term growth and negatively correlated with financial volatility, which provides preliminary evidence for our hypotheses.

Table 3 reports the regression results of the impact of CSR and its five dimensions on organizational resilience. Model 1 and Model 7 take the total CSR as the independent variable. Model 1 shows a positive and significant relationship $(\beta=0.0235 ; p<0.01)$ between total CSR and sales growth, indicating that CSR can improve a firm's long-term growth. Therefore, H1 is supported. In Model 7, the regression coefficient between total CSR and financial volatility was $-0.000537(p<0.01)$, indicating that CSR can significantly reduce financial volatility. Thus, we find support for $\mathrm{H} 2$. 
Table 2. Descriptive statistics and correlations $(\mathrm{N}=12,215)$.

\begin{tabular}{|c|c|c|c|c|c|c|c|c|c|c|c|c|c|c|}
\hline Variables & 1 & 2 & 3 & 4 & 5 & 6 & 7 & 8 & 9 & 10 & 11 & 12 & 13 & 14 \\
\hline 1. Growth & 1 & & & & & & & & & & & & & \\
\hline 2. Volatility & -0.00800 & 1 & & & & & & & & & & & & \\
\hline 3. CSR score & $0.206^{* * *}$ & $-0.141^{* * *}$ & 1 & & & & & & & & & & & \\
\hline 4. Shareholder & $0.110^{* * *}$ & $-0.098^{* * *}$ & $0.582^{* * *}$ & 1 & & & & & & & & & & \\
\hline 5. Employee & $0.197^{* * *}$ & $-0.094^{* * *}$ & $0.839 * * *$ & $0.242 * * *$ & 1 & & & & & & & & & \\
\hline 6. Business & $0.167^{* * *}$ & $-0.117^{* * *}$ & $0.876^{* * *}$ & $0.248 * * *$ & $0.826^{* * *}$ & 1 & & & & & & & & \\
\hline 7. Environment & $0.180^{* * *}$ & $-0.114^{* * *}$ & $0.841^{* * *}$ & $0.210^{* * *}$ & $0.865^{* * *}$ & $0.866^{* * *}$ & 1 & & & & & & & \\
\hline 8. Society & $0.099 * * *$ & $-0.078^{* * *}$ & $0.485^{* * *}$ & $0.278^{* * *}$ & $0.183^{* * *}$ & $0.255^{* * *}$ & $0.114^{* * *}$ & 1 & & & & & & \\
\hline 9. S\&A & $-0.020 * *$ & -0.00100 & -0.0140 & $0.080^{* * *}$ & $-0.076^{* * *}$ & -0.0130 & $-0.060^{* * *}$ & -0.00800 & 1 & & & & & \\
\hline 10. HHI & $-0.023^{* *}$ & -0.00300 & $-0.024^{* * *}$ & $-0.055^{* * *}$ & -0.00700 & -0.00700 & 0.00300 & -0.0130 & $-0.025^{* * *}$ & 1 & & & & \\
\hline 11. SOE & $0.084^{* * *}$ & $-0.051^{* * *}$ & $0.103^{* * *}$ & $-0.053^{* * *}$ & $0.155^{* * *}$ & $0.138^{* * *}$ & $0.144^{* * *}$ & 0.0130 & $-0.060 * * *$ & $0.023 * *$ & 1 & & & \\
\hline 12. MB & $0.216^{* * *}$ & $-0.204^{* * *}$ & $0.175^{* * *}$ & $-0.079 * * *$ & $0.225^{* * *}$ & $0.171^{* * *}$ & $0.198^{* * *}$ & $0.172 * * *$ & $-0.276 * * *$ & $-0.037^{* * *}$ & $0.140 * * *$ & 1 & & \\
\hline 13. LEV & $0.202^{* * *}$ & $-0.035^{* * *}$ & -0.00500 & $-0.331^{* * *}$ & $0.127^{* * *}$ & $0.082^{* * *}$ & $0.095^{* * *}$ & $0.095^{* * *}$ & $-0.157^{* * *}$ & 0.0110 & $0.166^{* * *}$ & $0.562 * * *$ & 1 & \\
\hline 14. $\mathrm{ACF}$ & $-0.047^{* * *}$ & -0.023 ** & $0.132 * * *$ & $0.341^{* * *}$ & 0.0120 & $0.035^{* * *}$ & $0.023 * *$ & 0.00500 & $0.109^{* * *}$ & $0.027^{* * *}$ & $-0.036 * * *$ & $-0.190 * * *$ & $-0.405 * * *$ & 1 \\
\hline Mean & 2.03 & 0.15 & 27.69 & 13.78 & 3.36 & 2.67 & 2.83 & 5.06 & 0.09 & 0.03 & 0.19 & 0.93 & 0.45 & 0.2 \\
\hline Median & 0.43 & 0.12 & 22.52 & 14.29 & 1.91 & 0 & 0 & 4.5 & 0.07 & 0.02 & 0 & 0.63 & 0.45 & 0.12 \\
\hline Std. Dev & 6.31 & 0.1 & 19.09 & 6.21 & 3.69 & 5.58 & 6.18 & 4.74 & 0.08 & 0.07 & 0.4 & 0.88 & 0.22 & 0.4 \\
\hline Minimum & -9.10 & 0.02 & -16.99 & -11.69 & -0.17 & 0 & 0 & -15 & 0 & 0 & 0 & 0.08 & 0.05 & -0.65 \\
\hline Maximum & 42.81 & 4.66 & 90.87 & 28.19 & 15 & 20 & 30 & 30 & 2.92 & 1 & 1 & 4.68 & 1.02 & 2.11 \\
\hline
\end{tabular}


Table 3. Regression results.

\begin{tabular}{|c|c|c|c|c|c|c|c|c|c|c|c|c|}
\hline \multirow{2}{*}{$\begin{array}{l}\text { Independent } \\
\text { Variables }\end{array}$} & \multicolumn{6}{|c|}{ Dependent Variable: Long-Term Growth } & \multicolumn{6}{|c|}{ Dependent Variable: Financial Volatility } \\
\hline & Model 1 & Model 2 & Model 3 & Model 4 & Model 5 & Model 6 & Model 7 & Model 8 & Model 9 & Model 10 & Model 11 & Model 12 \\
\hline Total CSR & $\begin{array}{c}0.0235^{* * *} \\
(0.00339)\end{array}$ & & & & & & $\begin{array}{l}-0.000537^{* * *} \\
\left(7.39 \times 10^{-5}\right)\end{array}$ & & & & & \\
\hline Shareholder & & $\begin{array}{c}0.0169 \\
(0.0110)\end{array}$ & & & & & & $\begin{array}{c}-0.00176^{* * *} \\
(0.000239)\end{array}$ & & & & \\
\hline Employee & & & $\begin{array}{l}0.123^{* * *} \\
(0.0182)\end{array}$ & & & & & & $\begin{array}{c}-0.00138^{* * *} \\
(0.000397)\end{array}$ & & & \\
\hline Business & & & & $\begin{array}{c}0.0644^{* * *} \\
(0.0112)\end{array}$ & & & & & & $\begin{array}{c}-0.00135^{* * * *} \\
(0.000243)\end{array}$ & & \\
\hline Environment & & & & & $\begin{array}{c}0.0836^{* * *} \\
(0.0101)\end{array}$ & & & & & & $\begin{array}{c}-0.00102 * * * \\
(0.000220)\end{array}$ & \\
\hline Society & & & & & & $\begin{array}{c}0.141 \\
(0.0857)\end{array}$ & & & & & & $\begin{array}{c}-0.00110^{* * *} \\
(0.000273)\end{array}$ \\
\hline S\&A & $\begin{array}{c}-1.800 * \\
(0.986)\end{array}$ & $\begin{array}{c}-1.822 * \\
(0.989)\end{array}$ & $\begin{array}{c}-2.081 * * \\
(0.986)\end{array}$ & $\begin{array}{c}-1.931 * \\
(0.987)\end{array}$ & $\begin{array}{c}-1.959 * * \\
(0.985)\end{array}$ & $\begin{array}{l}-2.587 \\
(6.759)\end{array}$ & $\begin{array}{c}-0.0548 \text { ** } \\
(0.0215)\end{array}$ & $\begin{array}{c}-0.0599 * * * \\
(0.0215)\end{array}$ & $\begin{array}{c}-0.0506 \text { ** } \\
(0.0215)\end{array}$ & $\begin{array}{c}-0.0519 * * \\
(0.0215)\end{array}$ & $\begin{array}{c}-0.0519 * * \\
(0.0215)\end{array}$ & $\begin{array}{c}-0.0558^{* * *} \\
(0.0215)\end{array}$ \\
\hline HHI & $\begin{array}{c}0.304 \\
(3.708)\end{array}$ & $\begin{array}{c}0.733 \\
(3.717)\end{array}$ & $\begin{array}{c}0.349 \\
(3.709)\end{array}$ & $\begin{array}{c}0.266 \\
(3.712)\end{array}$ & $\begin{array}{l}-0.118 \\
(3.705)\end{array}$ & $\begin{array}{l}-32.94 \\
(25.40)\end{array}$ & $\begin{array}{c}-0.601 * * * \\
(0.0808)\end{array}$ & $\begin{array}{c}-0.616^{* * *} \\
(0.0807)\end{array}$ & $\begin{array}{c}-0.606 * * * \\
(0.0809)\end{array}$ & $\begin{array}{c}-0.601 * * * \\
(0.0809)\end{array}$ & $\begin{array}{c}-0.600 * * * \\
(0.0809)\end{array}$ & $\begin{array}{c}-0.609 * * * \\
(0.0809)\end{array}$ \\
\hline SOE & $\begin{array}{l}0.0733 \\
(0.248)\end{array}$ & $\begin{array}{l}0.0886 \\
(0.248)\end{array}$ & $\begin{array}{l}0.0681 \\
(0.248)\end{array}$ & $\begin{array}{l}0.0597 \\
(0.248)\end{array}$ & $\begin{array}{l}0.0490 \\
(0.247)\end{array}$ & $\begin{array}{l}-0.327 \\
(1.696)\end{array}$ & $\begin{array}{c}-0.0174 * * * \\
(0.00539)\end{array}$ & $\begin{array}{c}-0.0184^{* * *} \\
(0.00539)\end{array}$ & $\begin{array}{c}-0.0174^{* * *} \\
(0.00540)\end{array}$ & $\begin{array}{c}-0.0171^{* * *} \\
(0.00540)\end{array}$ & $\begin{array}{c}-0.0172 * * * \\
(0.00540)\end{array}$ & $\begin{array}{c}-0.0176^{* * *} \\
(0.00540)\end{array}$ \\
\hline MB & $\begin{array}{c}3.045^{* * *} \\
(0.486)\end{array}$ & $\begin{array}{c}2.834 * * * \\
(0.498)\end{array}$ & $\begin{array}{c}2.719 * * * \\
(0.483)\end{array}$ & $\begin{array}{c}2.738^{* * *} \\
(0.484)\end{array}$ & $\begin{array}{c}2.799 * * * \\
(0.483)\end{array}$ & $\begin{array}{l}2.745 \\
(3.316)\end{array}$ & $\begin{array}{c}0.0909^{* * *} \\
(0.0106)\end{array}$ & $\begin{array}{c}0.0813^{* * *} \\
(0.0108)\end{array}$ & $\begin{array}{c}0.0991^{* * *} \\
(0.0105)\end{array}$ & $\begin{array}{c}0.0981 * * * \\
(0.0105)\end{array}$ & $\begin{array}{c}0.0980^{* * *} \\
(0.0105)\end{array}$ & $\begin{array}{c}0.0970 * * * \\
(0.0106)\end{array}$ \\
\hline LEV & $\begin{array}{c}-1.638 \text { **** } \\
(0.0987)\end{array}$ & $\begin{array}{c}-1.571^{* * * *} \\
(0.0984)\end{array}$ & $\begin{array}{c}-1.623 * * * \\
(0.0985)\end{array}$ & $\begin{array}{c}-1.626^{* * *} \\
(0.0988)\end{array}$ & $\begin{array}{c}-1.646^{* * *} \\
(0.0985)\end{array}$ & $\begin{array}{c}-3.238^{* * * *} \\
(0.673)\end{array}$ & $\begin{array}{c}-0.0599 * * * \\
(0.00215)\end{array}$ & $\begin{array}{c}-0.0611 \text { *** } \\
(0.00214)\end{array}$ & $\begin{array}{c}-0.0609^{* * *} \\
(0.00215)\end{array}$ & $\begin{array}{c}-0.0603^{* * *} \\
(0.00215)\end{array}$ & $\begin{array}{c}-0.0606^{* * *} \\
(0.00215)\end{array}$ & $\begin{array}{c}-0.0610^{* * *} \\
(0.00214)\end{array}$ \\
\hline $\mathrm{ACF}$ & $\begin{array}{c}-0.0669 \\
(0.157)\end{array}$ & $\begin{array}{c}-0.0466 \\
(0.158)\end{array}$ & $\begin{array}{c}-0.0302 \\
(0.157)\end{array}$ & $\begin{array}{c}-0.0173 \\
(0.157)\end{array}$ & $\begin{array}{c}-0.0245 \\
(0.157)\end{array}$ & $\begin{array}{c}0.713 \\
(1.074)\end{array}$ & $\begin{array}{l}0.000700 \\
(0.00342)\end{array}$ & $\begin{array}{c}0.00250 \\
(0.00344)\end{array}$ & $\begin{array}{c}-0.000271 \\
(0.00342)\end{array}$ & $\begin{array}{c}-0.000432 \\
(0.00342)\end{array}$ & $\begin{array}{c}-0.000329 \\
(0.00342)\end{array}$ & $\begin{array}{c}-0.000107 \\
(0.00342)\end{array}$ \\
\hline YFE & Yes & Yes & Yes & Yes & Yes & Yes & Yes & Yes & Yes & Yes & Yes & Yes \\
\hline FFE & Yes & Yes & Yes & Yes & Yes & Yes & Yes & Yes & Yes & Yes & Yes & Yes \\
\hline Constant & $\begin{array}{c}1.684^{* * *} \\
(0.298)\end{array}$ & $\begin{array}{c}2.115^{* * *} \\
(0.346)\end{array}$ & $\begin{array}{c}2.071^{* * *} \\
(0.283)\end{array}$ & $\begin{array}{c}2.295^{* * *} \\
(0.280)\end{array}$ & $\begin{array}{c}2.241^{* * *} \\
(0.279)\end{array}$ & $\begin{array}{l}4.905^{* *} \\
(1.974)\end{array}$ & $\begin{array}{l}0.203 \text { *** } \\
(0.00650)\end{array}$ & $\begin{array}{l}0.219^{* * *} \\
(0.00751)\end{array}$ & $\begin{array}{l}0.190^{* * *} \\
(0.00618)\end{array}$ & $\begin{array}{l}0.189 * * * \\
(0.00609)\end{array}$ & $\begin{array}{l}0.188^{* * *} \\
(0.00609)\end{array}$ & $\begin{array}{l}0.193^{* * *} \\
(0.00629)\end{array}$ \\
\hline$N$ & 12,215 & 12,215 & 12,215 & 12,215 & 12,215 & 12,215 & 12,215 & 12,215 & 12,215 & 12,215 & 12,215 & 12,215 \\
\hline No. of firms & 2444 & 2444 & 2444 & 2444 & 2444 & 2444 & 2444 & 2444 & 2444 & 2444 & 2444 & 2444 \\
\hline Adj. $R^{2}$ & 0.212 & 0.218 & 0.213 & 0.214 & 0.210 & 0.247 & 0.140 & 0.140 & 0.144 & 0.142 & 0.143 & 0.144 \\
\hline
\end{tabular}

Note: Standard errors in parentheses; ${ }^{* * *} p<0.01,{ }^{* *} p<0.05,{ }^{*} p<0.1$; YFE (year fixed effects), FFE (firm fixed effects). 
Models 2-6 take CSR's five dimensions as independent variables, and long-term growth as the dependent variable. In Model 2, the regression coefficient between the shareholder-related CSR and sales growth is 0.0169 , but not significant at the 0.1 level. These findings do not support H3. In Model 3-5, employee-related, business-related and environment-related CSR are taken as independent variables, and the regression coefficients are $0.123,0.0644$ and 0.0836 respectively, which are all significant at 0.01 level, indicating that all these three dimensions of CSR can improve a firm's long-term growth. Therefore, we find support for H5, H7, and H9. In Model 6, the regression coefficient between the society-related CSR and sales growth is 0.141 , but not significant at the 0.1 level. These findings do not support H11. It is to be noted that, the regression coefficient between the employee-related CSR and sales growth is obviously larger than other two significant coefficients, which to some extent indicating that employee-related CSR contributes most to a firm's long-term growth.

Models 8-12 take CSR's five dimensions as independent variables, and financial volatility as the dependent variable. The results show that the relationship between the shareholder-related, employee-related, business-related, environment-related and society-related and financial volatility are all significant at the 0.1 level, indicating $\mathrm{H} 4, \mathrm{H} 6, \mathrm{H} 8, \mathrm{H} 10$ and $\mathrm{H} 12$ are supported.

\subsection{Robustness Test Analysis}

As the different time periods used for measuring key variables may induce changes in empirical results, in the robustness analysis we use the accumulation of net sales growth over four years as the proxy variable for long-term growth, and weekly stock returns for financial volatility. The regression results shown in Appendix B are the same as those in Table 3, that is, the regression correlations between CSR, its five specific dimensions and financial volatility are still negative and significant; the regression correlations between total CSR, employee-related CSR, business-related CSR, environment-related CSR and long-term growth are still positive and significant; and the regression correlations shareholder-related CSR, society-related CSR and long-term growth are still nonsignificant. Also, compared to other dimensions of CSR, the employee-related CSR still contributes most to firms' long-term growth.

\section{Discussion and Conclusions}

Based on the operationalization of organizational resilience as a firm's long-term growth and financial volatility, this study adopts CSR's performance-enhancing and performance-insuring mechanism to analyze the impacts of CSR and its five dimensions on organizational resilience. Using the sample of listed non-financial Chinese companies during the period from 2010 to 2017, we find several new and interesting ideas about CSR and its effects on organizational resilience.

First, the engagement in CSR activities can improve a firm's long-term growth and reduce its financial volatility, which simultaneously supports the theoretical hypotheses of CSR's performance-enhancing and performance-insuring mechanism. This finding is consistent with the study of U.S-based companies conducted by Ortiz-de-Mandojana and Bansal [6], which shows the positive correlation between the social and the environmental practices and organizational resilience. Also, it further provides empirical evidence to verify and expand related views in extant conceptual or case studies $[4,5]$.

Second, all the five dimensions of CSR, i.e., shareholder, employee, business, environment, and society-related CSR, have a significant negative relationship with a firm's financial volatility, which supports the theoretical hypothesis of CSR's performance-insuring mechanism [23]. Because the discussion of CSR's performance-insuring mechanism has just emerged in last decade, the relevant empirical studies are still lacking, especially the quantitative analysis of CSR's specific dimensions. In this regard, we provide preliminary explanations and empirical evidence to enrich the existing literature.

Third, as for the performance-enhancing mechanism of CSR's five dimensions, the empirical result just indicates the significant associations between employee-, business- environment-related CSR and a firm's long-term growth. The reason why there is no significant relationship between 
shareholder-related CSR and long-term growth might be that the prudent investment decisions resulted from the requirement of sound financial structure, to some extent, limit the capital support needed to carry out innovative activities. As Kachaner and Stalk [63] point out, the long-lived family firms are likely to miss some business opportunities due to their prudent attitude towards capital investment, which makes them underperform the counterpart non-family firms, even though they can, as a result of cautious investments, benefit from limited risk exposure and therefore undergo less financial volatility during economic recessions.

For society-related CSR, its nonsignificant relationship with a firm's long-term growth might be due to the Chinese context applied in this study. As demonstrated at the outset, since the concern about CSR in China comes far later than that in developed countries, it is likely to be that due to the lack of social awareness, the performance-enhancing mechanism of society-related CSR has not been established. In this regard, compared to society-related CSR, Chinese enterprises' long-term growth might be dependent more on their good relationships with internal or major stakeholders, such as employees, customers, and suppliers. This inference can be further supported by the findings that employee-related CSR contributes most to a firm's long-term growth, as its regression correlation is obviously greater than other two significant correlations.

\subsection{Theoretical Contributions}

The theoretical contributions of this paper include the following aspects. First, we enrich the body of literature on the antecedents of organizational resilience. Due to the increasingly turbulent business environment, both academics and practitioners have paid much attention to organizational resilience, exploring how to help enterprises cope successfully with the impacts of environmental changes on their earning power profitability [1]. From the perspective of CSR, we discuss the role of the organization's relationships with various stakeholders on organizational resilience. Different from the extant studies that use a single, composite indicator $[19,92]$ or a broad, confusing classification $[25,27,29]$ to measure CSR, we analyze respectively the impacts of CSR's five basic dimensions on organizational resilience, i.e., shareholder, employee, business, environment, and society-related CSR, which provides direct, specific, and precise insights of the relationship between CSR and organizational resilience.

Second, this paper enriches the body of literature on the economic consequences of CSR. Prior work on CSR focuses mainly on its impact on a firm's short-term performance, which has been proved to be positive, negative or even nonsignificant in relevant studies [107-109]. These confusing and conflicting findings may be due to the fact that CSR, in a short term, increases a firm's operational costs and deviates from the goal of maximizing business interests [6]. This paper explores the impact of CSR on organizational resilience, and therefore provides empirical evidence of the relationship between CSR and corporate performance from a long-term perspective. The results show that the impact of CSR on corporate value is positive and cumulative or lagging over time [108]. Therefore, paying attention to this kind of activities will contribute to the long-term survival and development of enterprises $[6,110]$.

Third, consistent with the operationalization of organizational resilience as long-term growth and financial volatility, this paper discusses both CSR's performance-enhancing and performance-insuring mechanisms. The extant literature has mostly focused on CSR's performance-enhancing mechanism, discussing whether CSR has a positive impact on corporate performance or not [13-15]. Recently, several scholars have come up with that CSR can also provide insurance -like protections to a firm's financial performance, that is, CSR can protect a firm's financial performance from being extensively fluctuated during negative or adverse events [23]. Companies committed to CSR are kind of paying premiums, which can provide insurance for mitigating loss of corporate value and reducing financial volatility under crises [111]. Unfortunately, CSR's performance-insuring mechanism has not yet been fully explored. In this respect, our study supplements this emergent research stream with empirical evidence, and the results show that CSR and its dimensions all have a negative effect on financial volatility.

Forth, this paper enriches the extant literature on CSR and organizational resilience through providing evidence from emerging markets. Existing empirical studies on the economic consequences 
of CSR and the factors of organizational resilience are concentrated in developed countries and regions $[6,26,29,91,112]$, while the relevant assumptions are seldom examined by companies from the emerging markets [96]. Our study fills this gap and provides the first evidence of the impact of CSR's different dimensions on organizational resilience in the Chinese context. The results further confirm some theoretical hypotheses developed in previous studies of firms from developed markets. Also, we discover several new ideas that may be specific to the context of China. For example, society-related CSR does not have a significant impact on a firm's long-term growth, which may be due to the lack of relevant social awareness in China where the concern of CSR came late.

\subsection{Managerial Implications}

The increasingly turbulent business environment has made it very urgent for companies to build their organizational resilience. CSR is an important and necessary way for companies to achieve their organizational resilience in today's turbulent environment. Since enterprises are embedded in a social and economic system, they should actively engage in CSR activities to meet the needs of various stakeholders, so as to achieve their long-term sustainability. Our results suggest that the engagement in CSR activities contributes to enhancing long-term growth and reducing financial volatility. On the one hand, CSR can help a firm to build a wide network of knowledge and resources that increases its flexibility, efficiency and innovative activities, and thus facilitate to improve firm performance and stimulate long-term growth. On the other hand, when an enterprise is caught in disruptions, shocks, or crises, CSR can provide insurance-like protections to buffer the negative impacts of adverse events on its financial performance. Therefore, managers and owners should undertake investments in CSR practices and integrate them into the process of strategy formulation.

Furthermore, through providing direct relevance of CSR's specific dimensions (i.e., shareholder-, employee-, business-, environment, society-related CSR) to organizational resilience, our study has important managerial implications for firms to engage in CSR activities relevant to different stakeholders, so as to better promote firm growth and reduce financial volatility. While our results indicate that no significant relationships between shareholder, society-related CSR and a firm's long-term growth, it does not mean that shareholder and society-related CSR are not useful for organizational resilience, for they are still important in facing a negative or adverse event. In terms of shareholder-related CSR, as we explain above, the prudent investment decisions in line with the requirement of sound financial structure may impede the capital expenditure for innovative activities. To overcome this, managers and owners should wisely make a trade-off so as to capitalize on business opportunities to acquire high-level performance and growth. As for society-related CSR, its performance-enhancing mechanism is likely to be established with the rise of social concern of CSR in emerging markets. In this regard, managers and owners should engage in CSR activities that bring social welfare so as to build corporate reputation in public, which can also increase firm growth in the future.

\subsection{Limitations and Future Research}

This paper first explores the impact of CSR's specific dimensions on organizational resilience, and provides evidence of companies from emerging markets. The results reveal some new findings that deserve further research efforts. Meanwhile, several limitations of this study could be improved. First and most important, our sample is limited to only one country, China, so our research findings may or may not be context-dependent. Since this study comes up with several new findings that are different from those of prior work based on firms from developed countries, e.g., the nonsignificant relationships between society and shareholder-related CSR and a firm's long-term growth, we encourage future research to re-examine these findings using the sample of firms from other emerging markets, or go into more detail about why some dimensions of CSR have no performance-enhancing effects in a long run. Second, in this study, we do not include specific environmental changes that is essential to judge organizational resilience. Instead, we assess organizational resilience through its long-term outcomes, assuming a firm's ability to cope successfully with environmental changes is manifested 
in its persistent superior performance (i.e., high-level growth and low-level volatility over time). Therefore, through giving a specific environmental crisis, future research could draw conclusions about the precise effects of CSR and its different dimensions on organizational resilience.

Author Contributions: The authors contributed equally to this research.

Funding: This research received no external funding.

Conflicts of Interest: The authors declare no conflict of interest.

\section{Appendix A}

Table A1. The indicators of Hexun CSR evaluation.

\begin{tabular}{|c|c|c|}
\hline First-Order & Second-Order & Third-Order \\
\hline \multirow{5}{*}{ Shareholder (30\%) } & Earnings (10\%) & $\begin{array}{c}\text { Return on equity }(2 \%) \\
\text { Return on total assets }(2 \%) \\
\text { Profit margin of main business }(2 \%) \\
\text { Profit margin on cost }(1 \%) \\
\text { Earnings per share }(2 \%) \\
\text { Undistributed profit per share }(1 \%)\end{array}$ \\
\hline & Solvency $(3 \%)$ & $\begin{array}{c}\text { Quick ratio }(0.5 \%) \\
\text { Current ratio }(0.5 \%) \\
\text { Cash ratio }(0.5 \%) \\
\text { Shareholder equity ratio }(0.5 \%) \\
\text { Asset-liability ratio }(1 \%)\end{array}$ \\
\hline & Returns (8\%) & $\begin{array}{c}\text { Dividend-financing ratio }(2 \%) \\
\text { Dividend yield ( } 3 \%) \\
\text { Dividends-distributable profits ratio (3\%) }\end{array}$ \\
\hline & $\begin{array}{l}\text { Information disclosure } \\
(5 \%)\end{array}$ & $\begin{array}{l}\text { Number of penalties imposed by the stock exchange on the } \\
\text { company and relevant individuals in charge (5\%) }\end{array}$ \\
\hline & Innovation ( $4 \%)$ & $\begin{array}{c}\text { Expenditure on product development }(1 \%) \\
\text { Innovative ideas of technologies }(1 \%) \\
\text { Number of technological innovation projects (2\%) }\end{array}$ \\
\hline \multirow{3}{*}{$\begin{array}{l}\text { Employee }(15 \%) \\
\text { (10\% for consumer } \\
\text { industries) }\end{array}$} & Performance (5\%) & $\begin{array}{l}\text { Per capita income of employees }(4 \%)(3 \%) \\
\text { Staff training }(1 \%)(1 \%)\end{array}$ \\
\hline & Safety $(5 \%)$ & $\begin{array}{l}\text { Safety inspection }(2 \%)(1 \%) \\
\text { Safety training }(3 \%)(2 \%)\end{array}$ \\
\hline & Care $(5 \%)$ & $\begin{array}{c}\text { Awareness of condolences (1\%) }(1 \%) \\
\text { Condolences to employees }(2 \%)(1 \%) \\
\text { Condolence payments }(2 \%)(1 \%)\end{array}$ \\
\hline \multirow{3}{*}{$\begin{array}{l}\text { Business (including } \\
\text { suppliers, customer, and } \\
\text { consumer interests) }(15 \%) \\
\text { (20\% for consumer } \\
\quad \text { industries) }\end{array}$} & Product quality $(7 \%)$ & $\begin{array}{c}\text { Awareness of quality management (3\%) }(5 \%) \\
\text { Certificate of quality management system }(4 \%)(4 \%)\end{array}$ \\
\hline & After-sale services ( $3 \%)$ & Customer satisfaction survey $(3 \%)(4 \%)$ \\
\hline & $\begin{array}{l}\text { Integrity and } \\
\text { reciprocity (5\%) }\end{array}$ & $\begin{array}{c}\text { Fair competition among suppliers }(3 \%)(4 \%) \\
\text { Anti-bribery training }(2 \%)(3 \%)\end{array}$ \\
\hline $\begin{array}{c}\text { Environment }(20 \%) \\
(30 \%, 10 \% \text { for manufacturing } \\
\text { and service industries } \\
\text { respectively })\end{array}$ & $\begin{array}{l}\text { Environmental } \\
\text { governance }(20 \%)\end{array}$ & $\begin{array}{c}\text { Environmental awareness (2\%) }(4 \%)(2 \%) \\
\text { Certificate of environmental management system }(3 \%)(5 \%)(2 \%) \\
\text { Investment in environmental protection }(5 \%)(7 \%)(2 \%) \\
\text { Types of pollution discharge }(5 \%)(7 \%)(2 \%) \\
\text { Types of energy savings }(5 \%)(7 \%)(2 \%)\end{array}$ \\
\hline $\begin{array}{c}\text { Society }(20 \%) \\
(10 \%, 30 \% \text { for manufacturing } \\
\text { and service industries } \\
\text { respectively) }\end{array}$ & $\begin{array}{l}\text { Value contribution } \\
\qquad(20 \%)\end{array}$ & $\begin{array}{l}\text { Ratio of income tax to total profit } \\
(10 \%)(5 \%)(15 \%) \\
\text { Charitable donations } \\
(10 \%)(5 \%)(15 \%)\end{array}$ \\
\hline
\end{tabular}

Source: http://stock.hexun.com/2013-09-10/157898839.html. 


\section{Appendix B}

Table A2. Robustness test.

\begin{tabular}{|c|c|c|c|c|c|c|c|c|c|c|c|c|}
\hline \multirow{2}{*}{$\begin{array}{c}\text { Independent } \\
\text { Variables }\end{array}$} & \multicolumn{6}{|c|}{ Dependent Variable: Long-term Growth } & \multicolumn{6}{|c|}{ Dependent Variable: Financial Volatility } \\
\hline & Model 1 & Model 2 & Model 3 & Model 4 & Model 5 & Model 6 & Model 7 & Model 8 & Model 9 & Model 10 & Model 11 & Model 12 \\
\hline Total CSR & $\begin{array}{c}0.00894^{* *} \\
(0.00423)\end{array}$ & & & & & & $\begin{array}{c}-0.000296^{* * *} \\
(0.000454)\end{array}$ & & & & & \\
\hline Shareholder & & $\begin{array}{l}-0.0195 \\
(0.0137)\end{array}$ & & & & & & $\begin{array}{c}-0.000708^{* * *} \\
(0.000147)\end{array}$ & & & & \\
\hline Employee & & & $\begin{array}{c}0.0539 * * \\
(0.0227)\end{array}$ & & & & & & $\begin{array}{c}-0.000927^{* * *} \\
(0.000243)\end{array}$ & & & \\
\hline Business & & & & $\begin{array}{c}0.0285^{* *} \\
(0.0138)\end{array}$ & & & & & & $\begin{array}{c}-0.000846 * * * \\
(0.000149)\end{array}$ & & \\
\hline Environment & & & & & $\begin{array}{c}0.0466^{* * *} \\
(0.0123)\end{array}$ & & & & & & $\begin{array}{c}-0.000676^{* * *} \\
(0.000135)\end{array}$ & \\
\hline Society & & & & & & $\begin{array}{l}0.00938 \\
(0.0150)\end{array}$ & & & & & & $\begin{array}{c}-0.000559^{* * *} \\
(0.000168)\end{array}$ \\
\hline S\&A & $\begin{array}{l}-1.267 \\
(1.123)\end{array}$ & $\begin{array}{l}-1.359 \\
(1.125)\end{array}$ & $\begin{array}{l}-1.390 \\
(1.124)\end{array}$ & $\begin{array}{l}-1.312 \\
(1.124)\end{array}$ & $\begin{array}{l}-1.325 \\
(1.123)\end{array}$ & $\begin{array}{l}-1.267 \\
(1.124)\end{array}$ & $\begin{array}{c}-0.0461^{* * *} \\
(0.0132)\end{array}$ & $\begin{array}{c}-0.0478^{* * *} \\
(0.0132)\end{array}$ & $\begin{array}{c}-0.0435^{* * *} \\
(0.0132)\end{array}$ & $\begin{array}{c}-0.0445^{* * *} \\
(0.0132)\end{array}$ & $\begin{array}{c}-0.0444^{* * *} \\
(0.0132)\end{array}$ & $\begin{array}{c}-0.0465^{* * *} \\
(0.0132)\end{array}$ \\
\hline HHI & $\begin{array}{c}2.703 \\
(4.591)\end{array}$ & $\begin{array}{c}2.577 \\
(4.593)\end{array}$ & $\begin{array}{c}2.624 \\
(4.591)\end{array}$ & $\begin{array}{c}2.619 \\
(4.591)\end{array}$ & $\begin{array}{c}2.402 \\
(4.589)\end{array}$ & $\begin{array}{c}2.753 \\
(4.592)\end{array}$ & $\begin{array}{c}-0.264^{* * *} \\
(0.0496)\end{array}$ & $\begin{array}{c}-0.271^{* * * *} \\
(0.0496)\end{array}$ & $\begin{array}{c}-0.266^{* * *} \\
(0.0497)\end{array}$ & $\begin{array}{c}-0.263^{* * *} \\
(0.0496)\end{array}$ & $\begin{array}{c}-0.262^{* * *} \\
(0.0496)\end{array}$ & $\begin{array}{c}-0.268^{* * *} \\
(0.0497)\end{array}$ \\
\hline SOE & $\begin{array}{c}0.110 \\
(0.289)\end{array}$ & $\begin{array}{c}0.109 \\
(0.289)\end{array}$ & $\begin{array}{c}0.108 \\
(0.289)\end{array}$ & $\begin{array}{c}0.104 \\
(0.289)\end{array}$ & $\begin{array}{l}0.0937 \\
(0.289)\end{array}$ & $\begin{array}{c}0.116 \\
(0.289)\end{array}$ & $\begin{array}{c}-0.0116^{* * * *} \\
(0.00331)\end{array}$ & $\begin{array}{c}-0.0120^{* * *} \\
(0.00332)\end{array}$ & $\begin{array}{c}-0.0116^{* * *} \\
(0.00332)\end{array}$ & $\begin{array}{c}-0.0114 * * * \\
(0.00332)\end{array}$ & $\begin{array}{c}-0.0114 * * * \\
(0.00332)\end{array}$ & $\begin{array}{c}-0.0117^{* * * *} \\
(0.00332)\end{array}$ \\
\hline MB & $\begin{array}{c}2.902 * * * \\
(0.637)\end{array}$ & $\begin{array}{c}2.513 * * * \\
(0.650)\end{array}$ & $\begin{array}{c}2.786^{* * * *} \\
(0.632)\end{array}$ & $\begin{array}{c}2.786^{* * *} \\
(0.632)\end{array}$ & $\begin{array}{c}2.845^{* * * *} \\
(0.632)\end{array}$ & $\begin{array}{c}2.755^{* * *} \\
(0.633)\end{array}$ & $\begin{array}{l}0.0369^{* * * *} \\
(0.00650)\end{array}$ & $\begin{array}{l}0.0343^{* * *} \\
(0.00665)\end{array}$ & $\begin{array}{l}0.0413^{* * *} \\
(0.00647)\end{array}$ & $\begin{array}{l}0.0407^{* * *} \\
(0.00646)\end{array}$ & $\begin{array}{l}0.0407^{* * *} \\
(0.00647)\end{array}$ & $\begin{array}{l}0.0404 * * * \\
(0.00648)\end{array}$ \\
\hline LEV & $\begin{array}{c}-1.874^{* * *} \\
(0.121)\end{array}$ & $\begin{array}{c}-1.845^{* * *} \\
(0.120)\end{array}$ & $\begin{array}{c}-1.877^{* * *} \\
(0.121)\end{array}$ & $\begin{array}{c}-1.876^{* * *} \\
(0.121)\end{array}$ & $\begin{array}{c}-1.898^{* * *} \\
(0.121)\end{array}$ & $\begin{array}{c}-1.850^{* * *} \\
(0.120)\end{array}$ & $\begin{array}{c}-0.0315^{* * *} \\
(0.00132)\end{array}$ & $\begin{array}{c}-0.0322 * * * \\
(0.00131)\end{array}$ & $\begin{array}{c}-0.0320 * * * \\
(0.00132)\end{array}$ & $\begin{array}{c}-0.0316^{* * * *} \\
(0.00132)\end{array}$ & $\begin{array}{c}-0.0317^{* * *} \\
(0.00132)\end{array}$ & $\begin{array}{c}-0.0321 * * * * \\
(0.00132)\end{array}$ \\
\hline ACF & $\begin{array}{c}0.130 \\
(0.185)\end{array}$ & $\begin{array}{c}0.172 \\
(0.186)\end{array}$ & $\begin{array}{c}0.141 \\
(0.185)\end{array}$ & $\begin{array}{c}0.147 \\
(0.185)\end{array}$ & $\begin{array}{c}0.145 \\
(0.185)\end{array}$ & $\begin{array}{c}0.142 \\
(0.185)\end{array}$ & $\begin{array}{l}0.000173 \\
(0.00210)\end{array}$ & $\begin{array}{l}0.000748 \\
(0.00211)\end{array}$ & $\begin{array}{c}-0.000338 \\
(0.00210)\end{array}$ & $\begin{array}{c}-0.000458 \\
(0.00210)\end{array}$ & $\begin{array}{c}-0.000383 \\
(0.00210)\end{array}$ & $\begin{array}{c}-0.000274 \\
(0.00210)\end{array}$ \\
\hline YFE & Yes & Yes & Yes & Yes & Yes & Yes & Yes & Yes & Yes & Yes & Yes & Yes \\
\hline FFE & Yes & Yes & Yes & Yes & Yes & Yes & Yes & Yes & Yes & Yes & Yes & Yes \\
\hline Constant & $\begin{array}{c}2.952 * * * \\
(0.385) \\
\end{array}$ & $\begin{array}{c}3.628 * * * \\
(0.444) \\
\end{array}$ & $\begin{array}{c}3.085^{* * *} \\
(0.364) \\
\end{array}$ & $\begin{array}{c}3.183 * * * \\
(0.359) \\
\end{array}$ & $\begin{array}{c}3.127^{* * *} \\
(0.358) \\
\end{array}$ & $\begin{array}{c}3.195 * * * \\
(0.369) \\
\end{array}$ & $\begin{array}{l}0.106^{* * *} \\
(0.00399) \\
\end{array}$ & $\begin{array}{l}0.109 * * * \\
(0.00462) \\
\end{array}$ & $\begin{array}{c}0.0989^{* * *} \\
(0.00379) \\
\end{array}$ & $\begin{array}{l}0.0979^{* * *} \\
(0.00374)\end{array}$ & $\begin{array}{l}0.0977^{* * *} \\
(0.00374)\end{array}$ & $\begin{array}{l}0.0995^{* * *} \\
(0.00386)\end{array}$ \\
\hline$N$ & 9936 & 9936 & 9936 & 9936 & 9936 & 9936 & 12,214 & 12,214 & 12,214 & 12,214 & 12,214 & 12,214 \\
\hline No. of firms & 2328 & 2328 & 2328 & 2328 & 2328 & 2328 & 2444 & 2444 & 2444 & 2444 & 2444 & 2444 \\
\hline Adj. $R^{2}$ & 0.266 & 0.266 & 0.266 & 0.266 & 0.264 & 0.266 & 0.169 & 0.171 & 0.172 & 0.170 & 0.171 & 0.172 \\
\hline
\end{tabular}

Note: Standard errors in parentheses; ${ }^{* * *} p<0.01,{ }^{* *} p<0.05$; YFE (year fixed effects), FFE (firm fixed effects). 


\section{References}

1. Hamel, G.; Valikangas, L. The quest for resilience. Harv. Bus. Rev. 2003, 81, 52-63. [PubMed]

2. Teixeira, E.D.; Werther, W.B. Resilience: Continuous renewal of competitive advantages. Bus. Horiz. 2013, 56, 333-342. [CrossRef]

3. Gao, C.; Zuzul, T.; Jones, G.; Khanna, T. Overcoming institutional voids: A reputation-based view of long-run survival. Strateg. Manag. J. 2017, 38, 2147-2167. [CrossRef]

4. Pal, R.; Torstensson, H.; Mattila, H. Antecedents of organizational resilience in economic crises-an empirical study of swedish textile and clothing SMEs. Int. J. Prod. Econ. 2014, 147, 410-428. [CrossRef]

5. Cho, S.; Mathiassen, L.; Robey, D. Dialectics of resilience: A multi-level analysis of a telehealth innovation. J. Inf. Technol. 2007, 22, 24-35. [CrossRef]

6. Ortiz-de-Mandojana, N.; Bansal, P. The long-term benefits of organizational resilience through sustainable business practices. Strateg. Manag. J. 2016, 37, 1615-1631. [CrossRef]

7. Markman, G.M.; Venzin, M. Resilience: Lessons from banks that have braved the economic crisis-and from those that have not. Int. Bus. Rev. 2014, 23, 1096-1107. [CrossRef]

8. Reinmoeller, P.; van Baardwijk, N. The link between diversity and resilience. MIT Sloan Manag. Rev. 2005, 46, 61-65.

9. Pal, R. Organizational resilience and health of business systems. Int. J. Bus. Contin. Risk Manag. 2011, 2, 372-398. [CrossRef]

10. Blanco, J.M.M.; Montes-Botella, J.L. Exploring nurtured company resilience through human capital and human resource development findings from spanish manufacturing companies. Int. J. Manpow. 2017, 38, 661-674. [CrossRef]

11. Bode, C.; Singh, J.; Rogan, M. Corporate social initiatives and employee retention. Organ. Sci. 2015, 26, 1702-1720. [CrossRef]

12. Wei, Y.C.; Egri, C.P.; Lin, C.Y.Y. Do corporate social responsibility practices yield different business benefits in eastern and western contexts? Chin. Manag. Stud. 2014, 8, 556-576. [CrossRef]

13. Wisse, B.; van Eijbergen, R.; Rietzschel, E.F.; Scheibe, S. Catering to the needs of an aging workforce: The role of employee age in the relationship between corporate social responsibility and employee satisfaction. J. Bus. Ethics 2018, 147, 875-888. [CrossRef]

14. Barakat, S.R.; Isabella, G.; Boaventura, J.M.G.; Mazzon, J.A. The influence of corporate social responsibility on employee satisfaction. Manag. Decis. 2016, 54, 2325-2339. [CrossRef]

15. Abdelmotaleb, M.; Metwally, A.; Saha, S.K. Exploring the impact of being perceived as a socially responsible organization on employee creativity. Manag. Decis. 2018, 56, 2325-2340. [CrossRef]

16. Bocquet, R.; Le Bas, C.; Mothe, C.; Poussing, N. CSR, innovation, and firm performance in sluggish growth contexts: A firm-level empirical analysis. J. Bus. Ethics 2017, 146, 241-254. [CrossRef]

17. Chang, C.H. Proactive and reactive corporate social responsibility: Antecedent and consequence. Manag. Decis. 2015, 53, 451-468. [CrossRef]

18. Singh, J. The influence of csr and ethical self-identity in consumer evaluation of cobrands. J. Bus. Ethics 2016, 138, 311-326. [CrossRef]

19. Zou, P.; Li, G.F. How emerging market investors' value competitors' customer equity: Brand crisis spillover in China. J. Bus. Res. 2016, 69, 3765-3771. [CrossRef]

20. Wang, D.H.M.; Chen, P.H.; Yu, T.H.K.; Hsiao, C.Y. The effects of corporate social responsibility on brand equity and firm performance. J. Bus. Res. 2015, 68, 2232-2236. [CrossRef]

21. Benlemlih, M.; Bitar, M. Corporate social responsibility and investment efficiency. J. Bus. Ethics 2018, 148, 647-671. [CrossRef]

22. Shiu, Y.M.; Yang, S.L. Does engagement in corporate social responsibility provide strategic insurance-like effects? Strateg. Manag. J. 2017, 38, 455-470. [CrossRef]

23. Godfrey, P.C.; Merrill, C.B.; Hansen, J.M. The relationship between corporate social responsibility and shareholder value: An empirical test of the risk management hypothesis. Strateg. Manag. J. 2009, 30, 425-445. [CrossRef]

24. Freeman, R. Strategic Management: A Stakeholder Perspective; HarperCollins College Div: New York, NY, USA, 1984. 
25. Mattingly, J.E.; Berman, S.L. Measurement of corporate social action: Discovering taxonomy in the kinder lydenburg domini ratings data. Bus. Soc. 2006, 45, 20-46. [CrossRef]

26. Su, W.C.; Tsang, E.W.K. Product diversification and financial performance: The moderating role of secondary stakeholders. Acad. Manag. J. 2015, 58, 1128-1148. [CrossRef]

27. Freeman, R.; Harrison, J.; Wicks, A.; Parmar, B.; De Colle, S. Stakeholder Theory: The State of the Art; Cambridge University Press: Cambridge, UK, 2010.

28. Eesley, C.; Lenox, M.J. Firm responses to secondary stakeholder action. Strateg. Manag. J. 2006, $27,765-781$. [CrossRef]

29. Hawn, O.; Ioannou, I. Mind the gap: The interplay between external and internal actions in the case of corporate social responsibility. Strateg. Manag. J. 2016, 37, 2569-2588. [CrossRef]

30. Folke, C. Resilience: The emergence of a perspective for social-ecological systems analyses. Glob. Environ. Chang. 2006, 16, 253-267. [CrossRef]

31. Holling, C.S. Resilience and stability of ecological systems. Annu. Rev. Ecol. Syst. 1973, 4, 1-23. [CrossRef]

32. Walker, B.; Holling, C.S.; Carpenter, S.R.; Kinzig, A.P. Resilience, adaptability and transformability in social-ecological systems. Ecol. Soc. 2004, 9, 3438-3447. [CrossRef]

33. Weick, K.; Sutcliffe, K. Managing the Unexpected: Resilient Performance in an Age of Uncertainty; John Wiley \& Sons: Hoboken, NJ, USA, 2001.

34. Sheffi, Y.; Rice, J.B. A supply chain view of the resilient enterprise. MIT Sloan Manag. Rev. 2005, 47, 41-48.

35. Gittell, J.H. Relationships and resilience care provider responses to pressures from managed care. J. Appl. Behav. Sci. 2008, 44, 25-47. [CrossRef]

36. Van der Vegt, G.S.; Essens, P.; Wahlstrom, M.; George, G. Managing risk and resilience. Acad. Manag. J. 2015, 58, 971-980. [CrossRef]

37. Fiksel, J.; Polyviou, M.; Croxton, K.L.; Pettit, T.J. From risk to resilience: Learning to deal with disruption. MIT Sloan Manag. Rev. 2015, 56, 79-86.

38. Luthans, F. The need for and meaning of positive organizational behavior. J. Organ. Behav. 2002, 23, 695-706. [CrossRef]

39. Coutu, D.L. How resilience works. Harv. Bus. Rev. 2002, 80, 46-54.

40. Acquaah, M.; Amoako-Gyampah, K.; Jayaram, J. Resilience in family and nonfamily firms: An examination of the relationships between manufacturing strategy, competitive strategy and firm performance. Int. J. Prod. Res. 2011, 49, 5527-5544. [CrossRef]

41. Reeves, M.; Levin, S.; Ueda, D. The biology of corporate survival. Harv. Bus. Rev. 2016, 94, 47-55.

42. Sutcliffe, K.M.; Vogus, T.J. Organizing for resilience. In Positive Organizational Scholarship: Foundations of a New Discipline, 1st ed.; Cameron, K.S., Dutton, J.E., Quinn, R.E., Eds.; Berrett-Koehler Publishers: Oakland, CA, USA, 2003; pp. 94-110.

43. Smallbone, D.; Deakins, D.; Battisti, M.; Kitching, J. Small business responses to a major economic downturn: Empirical perspectives from new zealand and the United Kingdom. Int. Small Bus. J. 2012, 30, 754-777. [CrossRef]

44. Lampel, J.; Bhalla, A.; Jha, P.P. Does governance confer organisational resilience? Evidence from UK employee owned businesses. Eur. Manag. J. 2014, 32, 66-72.

45. Mackey, A.; Mackey, T.B.; Barney, J.B. Corporate social responsibility and firm performance: Investor preferences and corporate strategies. Acad. Manag. Rev. 2007, 32, 817-835. [CrossRef]

46. Ortas, E.; Moneva, J.M.; Burritt, R.; Tingey-Holyoak, J. Does sustainability investment provide adaptive resilience to ethical investors? Evidence from Spain. J. Bus. Ethics 2014, 124, 297-309. [CrossRef]

47. Lengnick-Hall, C.A.; Beck, T.E. Adaptive fit versus robust transformation: How organizations respond to environmental change. J. Manag. 2005, 31, 738-757. [CrossRef]

48. Gunasekaran, A.; Rai, B.K.; Griffin, M. Resilience and competitiveness of small and medium size enterprises: An empirical research. Int. J. Prod. Res. 2011, 49, 5489-5509. [CrossRef]

49. Chan, M.C.; Watson, J.; Woodliff, D. Corporate governance quality and CSR disclosures. J. Bus. Ethics 2014, 125, 59-73. [CrossRef]

50. Cui, J.; Jo, H.; Na, H. Does corporate social responsibility affect information asymmetry? J. Bus. Ethics 2018, 148, 549-572. [CrossRef]

51. Cheung, Y.L.; Tan, W.Q.; Wang, W.M. National stakeholder orientation, corporate social responsibility, and bank loan cost. J. Bus. Ethics 2018, 150, 505-524. [CrossRef] 
52. Cheng, B.T.; Ioannou, I.; Serafeim, G. Corporate social responsibility and access to finance. Strateg. Manag. J. 2014, 35, 1-23. [CrossRef]

53. Attig, N.; Cleary, S.W.; El Ghoul, S.; Guedhami, O. Corporate legitimacy and investment-cash flow sensitivity. J. Bus. Ethics 2014, 121, 297-314.

54. Werner, T. Gaining access by doing good: The effect of sociopolitical reputation on firm participation in public policy making. Manag. Sci. 2015, 61, 1989-2011. [CrossRef]

55. McDonnell, M.-H.; King, B. Keeping up appearances: Reputational threat and impression management after social movement boycotts. Adm. Sci. Q. 2013, 58, 387-419. [CrossRef]

56. Zavyalova, A.; Pfarrer, M.D.; Reger, R.K.; Hubbard, T.D. Reputation as a benefit and a burden? How stakeholders' organizational identification affects the role of reputation following a negative event. Acad. Manag. J. 2016, 59, 253-276. [CrossRef]

57. Bromiley, P. Testing a causal model of corporate risk taking and performance. Acad. Manag. J. 1991, 34, 37-59.

58. Nickel, M.N.; Rodriguez, M.C. A review of research on the negative accounting relationship between risk and return: Bowman's paradox. Omega 2002, 30, 1-18. [CrossRef]

59. Shi, G.F.; Sun, J.F. Corporate bond covenants and social responsibility investment. J. Bus. Ethics 2015, 131, 285-303. [CrossRef]

60. Wang, X.; Cao, F.; Ye, K.T. Mandatory corporate social responsibility (CSR) reporting and financial reporting quality: Evidence from a quasi-natural experiment. J. Bus. Ethics 2018, 152, 253-274. [CrossRef]

61. Peric, M.; Vitezic, V. Impact of global economic crisis on firm growth. Small Bus. Econ. 2016, 46, 1-12. [CrossRef]

62. Tognazzo, A.; Gubitta, P.; Favaron, S.D. Does slack always affect resilience? A study of quasi-medium-sized italian firms. Entrep. Reg. Dev. 2016, 28, 768-790. [CrossRef]

63. Kachaner, N.; Stalk, G.; Bloch, A. What you can learn from family business. Harv. Bus. Rev. 2012, 90, $102-106$.

64. Govindarajan, V.; Srivastava, A. The scary truth about corporate survival. Harv. Bus. Rev. 2016, 94, $24-25$.

65. Wastell, D.G.; McMaster, T.; Kawalek, P. The rise of the phoenix: Methodological innovation as a discourse of renewal. J. Inf. Technol. 2007, 22, 59-68. [CrossRef]

66. Ates, A.; Bititci, U. Change process: A key enabler for building resilient SMEs. Int. J. Prod. Res. 2011, 49, 5601-5618. [CrossRef]

67. Jaaron, A.A.M.; Backhouse, C.J. Service organisations resilience through the application of the vanguard method of systems thinking: A case study approach. Int. J. Prod. Res. 2014, 52, 2026-2041. [CrossRef]

68. Sabatino, M. Economic crisis and resilience: Resilient capacity and competitiveness of the enterprises. J. Bus. Res. 2016, 69, 1924-1927. [CrossRef]

69. Shen, J.; Benson, J. When CSR is a social norm: How socially responsible human resource management affects employee work behavior. J. Manag. 2016, 42, 1723-1746. [CrossRef]

70. Demmer, W.A.; Vickery, S.K.; Calantone, R. Engendering resilience in small- and medium-sized enterprises (SMEs): A case study of demmer corporation. Int. J. Prod. Res. 2011, 49, 5395-5413. [CrossRef]

71. Lengnick-Hall, C.A.; Beck, T.E.; Lengnick-Hall, M.L. Developing a capacity for organizational resilience through strategic human resource management. Hum. Resour. Manag. Rev. 2011, 21, 243-255. [CrossRef]

72. Yacob, S. Trans-generational renewal as managerial succession: The behn meyer story (1840-2000). Bus. Hist. 2012, 54, 1166-1185. [CrossRef]

73. Shan, L.; Fu, S.; Zheng, L. Corporate sexual equality and firm performance. Strateg. Manag. J. 2017, 38, 1812-1826. [CrossRef]

74. Stoian, C.; Gilman, M. Corporate social responsibility that "pays": A strategic approach to CSR for smes. J. Small Bus. Manag. 2017, 55, 5-31. [CrossRef]

75. Gittell, J.H.; Cameron, K.; Lim, S.; Rivas, V. Relationships, layoffs, and organizational resilience airline industry responses to September 11. J. Appl. Behav. Sci. 2006, 42, 300-329. [CrossRef]

76. Van Essen, M.; Strike, V.M.; Carney, M.; Sapp, S. The resilient family firm: Stakeholder outcomes and institutional effects. Corp. Gov. Int. Rev. 2015, 23, 167-183. [CrossRef]

77. Moore, J.F. The Death of Competition: Leadership and Strategy in the Age of Business Ecosystems; HarperBusiness: New York, NY, USA, 1996.

78. Erol, O.; Sauser, B.J.; Mansouri, M. A framework for investigation into extended enterprise resilience. Enterp. Inf. Syst. 2010, 4, 111-136. [CrossRef] 
79. Marwa, S.; Zairi, M. An exploratory study of the reasons for the collapse of contemporary companies and their link with the concept of quality. Manag. Decis. 2008, 46, 1342-1370. [CrossRef]

80. Zhang, M.; Jin, B.Y.; Wang, G.A.; Goh, T.N.; He, Z. A study of key success factors of service enterprises in china. J. Bus. Ethics 2016, 134, 1-14. [CrossRef]

81. Day, G.S. Closing the marketing capabilities gap. J. Mark. 2011, 75, 183-195. [CrossRef]

82. Leguizamon, F.; Selva, G.; Santos, M. Small farmer suppliers from local to global. J. Bus. Res. 2016, 69, 4520-4525. [CrossRef]

83. Asgary, N.; Li, G. Corporate social responsibility: Its economic impact and link to the bullwhip effect. J. Bus. Ethics 2016, 135, 665-681. [CrossRef]

84. Winston, A. Resilience in a hotter world. Harv. Bus. Rev. 2014, 92, 56-64.

85. Zhang, M.; Ma, L.J.; Su, J.; Zhang, W. Do suppliers applaud corporate social performance? J. Bus. Ethics 2014, 121, 543-557. [CrossRef]

86. Sharfman, M.P.; Fernando, C.S. Environmental risk management and the cost of capital. Strateg. Manag. J. 2008, 29, 569-592. [CrossRef]

87. Cordeiro, J.J.; Tewari, M. Firm characteristics, industry context, and investor reactions to environmental CSR: A stakeholder theory approach. J. Bus. Ethics 2015, 130, 833-849. [CrossRef]

88. Russo, M.V.; Harrison, N.S. Organizational design and environmental performance: Clues from the electronics industry. Acad. Manag. J. 2005, 48, 582-593. [CrossRef]

89. Cho, S.Y.; Lee, C.; Pfeiffer, R.J. Corporate social responsibility performance and information asymmetry. J. Account. Public Policy 2013, 32, 71-83. [CrossRef]

90. Orlitzky, M.; Schmidt, F.L.; Rynes, S.L. Corporate social and financial performance: A meta-analysis. Organ. Stud. 2003, 24, 403-441. [CrossRef]

91. Verbeeten, F.H.M.; Gamerschlag, R.; Moller, K. Are CSR disclosures relevant for investors? Empirical evidence from Germany. Manag. Decis. 2016, 54, 1359-1382. [CrossRef]

92. Gautier, A.; Pache, A.C. Research on corporate philanthropy: A review and assessment. J. Bus. Ethics 2015, 126, 343-369. [CrossRef]

93. File, K.M.; Prince, R.A. Cause related marketing and corporate philanthropy in the privately held enterprise. J. Bus. Ethics 1998, 17, 1529-1539. [CrossRef]

94. Zhao, M. CSR-based political legitimacy strategy: Managing the state by doing good in China and Russia. J. Bus. Ethics 2012, 111, 439-460. [CrossRef]

95. Xavier, W.G.; Bandeira-de-Mello, R.; Marcon, R. Institutional environment and business groups' resilience in Brazil. J. Bus. Res. 2014, 67, 900-907. [CrossRef]

96. Su, W.; Peng, M.W.; Tan, W.Q.; Cheung, Y.L. The signaling effect of corporate social responsibility in emerging economies. J. Bus. Ethics 2016, 134, 479-491. [CrossRef]

97. Wang, H.L.; Qian, C.L. Corporate philanthropy and corporate financial performance: The roles of stakeholder response and political access. Acad. Manag. J. 2011, 54, 1159-1181. [CrossRef]

98. Godfrey, P.C. The relationship between corporate philanthropy and shareholder wealth: A risk management perspective. Acad. Manag. Rev. 2005, 30, 777-798. [CrossRef]

99. Thomas, A.; Byard, P.; Francis, M.; Fisher, R.; White, G.R.T. Profiling the resiliency and sustainability of UK manufacturing companies. J. Manuf. Technol. Manag. 2016, 27, 82-99. [CrossRef]

100. Schwert, G.W. Stock market volatility. Financ. Anal. J. 1990, 46, 23-34. [CrossRef]

101. Hu, Y.; Chen, S.; Shao, Y.; Gao, S. CSR and firm value: Evidence from China. Sustainability 2018, $10,4597$. [CrossRef]

102. Song, M.-L.; Fisher, R.; Wang, J.-L.; Cui, L.-B. Environmental performance evaluation with big data: Theories and methods. Ann. Oper. Res. 2018, 270, 459-472. [CrossRef]

103. Feltham, G.A.; Ohlson, J.A. Valuation and clean surplus accounting for operating and financial activities. Contemp. Account. Res. 1995, 11, 689-731. [CrossRef]

104. Fama, E.F.; French, K.R. Value versus growth: The international evidence. J. Financ. 1998, 53, $1975-1999$. [CrossRef]

105. Ahmed, M.U.; Kristal, M.M.; Pagell, M. Impact of operational and marketing capabilities on firm performance: Evidence from economic growth and downturns. Int. J. Prod. Econ. 2014, 154, 59-71. [CrossRef]

106. Andersen, T.J. Multinational risk and performance outcomes: Effects of knowledge intensity and industry context. Int. Bus. Rev. 2012, 21, 239-252. [CrossRef] 
107. Chen, C.J.; Guo, R.S.; Hsiao, Y.C.; Chen, K.L. How business strategy in non-financial firms moderates the curvilinear effects of corporate social responsibility and irresponsibility on corporate financial performance. J. Bus. Res. 2018, 92, 154-167. [CrossRef]

108. Chen, R.C.Y.; Lee, C.H. Assessing whether corporate social responsibility influence corporate valuee. Appl. Econ. 2017, 49, 5547-5557. [CrossRef]

109. McWilliams, A.; Siegel, D. Corporate social responsibility and financial performance: Correlation or misspecification? Strateg. Manag. J. 2000, 21, 603-609. [CrossRef]

110. Ahn, S.Y.; Park, D.J. Corporate social responsibility and corporate longevity: The mediating role of social capital and moral legitimacy in Korea. J. Bus. Ethics 2018, 150, 117-134. [CrossRef]

111. Peloza, J. Using corporate social responsibility as insurance for financial performance. Calif. Manag. Rev. 2006, 48, 52-72. [CrossRef]

112. Vidaver-Cohen, D.; Bronn, P.S. Reputation, responsibility, and stakeholder support in scandinavian firms: A comparative analysis. J. Bus. Ethics 2015, 127, 49-64. [CrossRef]

(C) 2019 by the authors. Licensee MDPI, Basel, Switzerland. This article is an open access article distributed under the terms and conditions of the Creative Commons Attribution (CC BY) license (http:// creativecommons.org/licenses/by/4.0/). 